\title{
Antioxidant Activities of Terpenoids from Thuidium tamariscellum (C. Muell.) Bosch. and Sande-Lac. a Moss
}

\author{
Greeshma Geetha Mohandas', Murugan Kumaraswamy*2
}

\section{Greeshma Geetha Mohandas ${ }^{1}$, Murugan Kumaraswamy ${ }^{2 *}$}

'Department of botany University college Palayam Trivandrum Kerala, INDIA. ${ }^{2}$ Department of Botany and Biotechnology, Govt. Arts College, Thiruvananthapuram, Kerala, INDIA.

\section{Correspondence}

\section{Murugan Kumaraswamy}

Department of Botany and Biotechnology, Govt. Arts College, Thiruvananthapuram, Kerala, INDIA.

Phone no : 9447077895

E-mail: harimurukan@gmail.com

History

- Submission Date: 03-01-2018;

- Review completed: 14-02-2018;

- Accepted Date: 05-03-2018

DOI : 10.5530/pj.2018.4.106

Article Available online http://www.phcogj.com/v10/i4

\section{Copyright}

(C) 2018 Phcog.Net. This is an openaccess article distributed under the terms of the Creative Commons Attribution 4.0 International license.

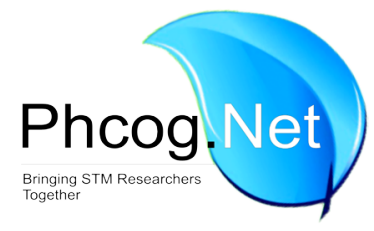

\begin{abstract}
Introduction: Thuidium tamariscellum is a small creeping epiphytic moss growing on trunks and branches of trees as well as on moist shady rocky surface at high altitudes areas. Methods: The present study was undertaken to analyze the phytochemicals in the species and its antioxidant potentialities interms of DPPH, ABTS, $\mathrm{H}_{2} \mathrm{O}_{2}$, FRAP and metal chelating ability. Results: Total terpenoids level was remarkable. Interestingly, a concentration dependent free radical scavenging potential was noticed and was comparable with the synthetic antioxidant ascorbate. Further, the FTIR analysis of petroleum ether, chloroform, ethyl acetate, and methanol extract confirmed the presence of alcohols/phenols, primary, secondary amines, amides, alkanes, aldehydes, saturated aliphatic alkenes aromatics and aromatic amines, nitro compounds, carboxylic acids, esters, ethers, aliphatic amines, alkyl halides and carbonyls in the moss indicating the presence of medicinally important compounds like flavonoids, terpenoids and alkaloids in the various solvent extracts of the moss. Conclusion: The overall result of the present study showed that the moss is rich in important pharmaceutical compounds and was reflected as its antioxidant potential. Further studies are warranted to isolate, identify and purify the lead terpenoid present in the moss.

Key words: Moss, Phenols, Terpenoids, Thuidium tamariscellum.
\end{abstract}

\section{INTRODUCTION}

Bryophytes are the second largest group of plants after the flowering plants. About 20,000 members were documented from all over the world. Out of which 3000 bryophytes were reported to possess medicinal properties. They are primitive non-vascular plants and include liverworts, hornworts and mosses as three distinct groups. These plants were traditionally used in Chinese, European and Indian medicine to treat various illness including skin diseases and bronchitis. Numerous biologically active compounds were reported from these plants such as phenolic compounds, alkaloids, flavonoids and terpenoids. Plagiochila beddomei is a liverwort reported to possess the phenolic acids like coumaric acid, Ferulic acid, gallic acid, caffeic acid, cinnamic acid, sinapic acid and hydroxyl benzoic acid. ${ }^{1}$ There is no authentic historical record, describing the application of liverworts and mosses in Ayurveda, the Indian system of medicine. Interestingly, mosses such as Barbula, Fissidenc, Minium, Thuidium and species of liverworts like Asterella, Dumortiera, Marchantia, Pellia, Plagiochasma and Stephenrencella-Anthoceros were revealed the occurrence of minerals and metals in their thallus like copper, silver, zinc, iron, lead etc. ${ }^{2}$ Chinese ethnic usage revealed 40 kinds of bryophytes employed in cardiovascular diseases, tonsillitis, bronchitis, cystitis, and skin infections. Similarly, Fissidens and Polytrichum were utilized as diuretic and hair growth stimulating drugs long back of 400 years ago. Marchantía polymorpha was employed in curing liver diseases like jaundice and hepatitis. In China, Rhodobryum giganteum and R. roseum were used in the treatment of heart ailments. ${ }^{3}$

Bryum, Mnium, Philonotis spp., and Polytrichum juniperinum were used by the North American, Indians to heal burns, bruises, and wounds.The Seminole people in North America were reported to use Barbula unguiculata as medicinal. Similarly, Bryum capillare and Octoblepharum albidum were used as febrifuge and antidote against poison. Willow moss, Fontinalis antipyretica was reputed as a febrifuge. Dried Sphagnum was used extensively as a surgical dressing material during the First World War. In France, Marchantia polymorpha was used to promote diuresis. In the Himalayas, Riccia sp. was used for the treatment of Tinea (ringworm) infestations. The use of bryophytes as antibacterial or disinfectant agents deserves special mention. Sphagnum teres was used in ophthalmologic diseases. In China and Bolivia, Fissidens osmundoides was used as an antibacterial agent to treat inflammatory conditions of the pharynx and larynx. Haplocladium microphyllum was used as a demulcent medicine in inflammatory conditions like bronchitis, cystitis, tonsillitis and tympanitis. Philonotis fontana was used by Go suite native people as a soothing preparation for healing burns. $^{2}$
Cite this article: Mohandas GG, Kumaraswamy M. Antioxidant Activities of Terpenoids from Thuidium tamariscellum (C. Muell.) Bosch. and Sande-Lac. a Moss. Pharmacog J. 2018;10(4):6459. 
Chetna Sharma et al. ${ }^{4}$ reported that the phenolic compounds present in the methanolic extract of Reboulia hemispherica exhibited microbicidal potential against Staphylococcus aureus indicating their therapeutic potentiality. Hari Datta et al. ${ }^{5}$ reported Sanionia uncinata a polar moss as an important source of natural antioxidant agents and Boris pejin et al. ${ }^{6}$ reported the moss Bryum moravicum possess potential antioxidant activity. Similarly, the ethanolic extracts of Atrichum undulatum, Polythrichum formosum (Polytrichaceae) possess stronger antioxidant activity. ${ }^{7}$ Fifilyana et al. ${ }^{8}$ reported Sphagnum cuspidatum subsp. subrecurvum, Sphagnum cuspidatulum, Sphagnum junghuhniannum, Pogonatum cirratum subsp. fuscatum and Pogonatum cirratum subsp. macrophyllum contained considerable amount of phenolics and flavonoids which contribute to their antioxidant properties.

Fourier Transformer Infra-red (FTIR) Spectrometry is also a valuable tool for the identification of biologically active compounds based on their functional groups and chemical compounds present in the plant extracts. But, still the experimental evidence regarding their usage among bryophytes is not fully proved. So, in this scenario, the aim of the present study was to identify the functional groups present in the various solvent extracts of Thuidium tamariscellum by FTIR analysis and also to evaluate the antioxidant potentiality of the moss.

\section{MATERIALS AND METHODS}

\section{Plant material}

Thuidium tamariscellum (Thuidiaceae) identity was confirmed by floras and authenticated by comparing with the herbarium of University of Calicut.

\section{Estimation of terpenoids}

Total terpenoids was determined by the method of Ferguson. ${ }^{9}$

\section{Antioxidant assays \\ DPPH Radical Scavenging Assay}

2, 2-diphenyl-1-picryl-hydrazyl-hydrate (DPPH) antioxidant method as described by Blois ${ }^{10}$ was used to analyze the free radical scavenging ability of the moss and the absorbance was measured at $517 \mathrm{~nm}$. Ascorbic acid was used as the standard.

\section{$A B T S^{+}$radical scavenging assay}

The 2,2'-azino-bis-3-ethylbenzothiazoline-6-sulphonic acid (ABTS) assay ${ }^{1}$ is based on the oxidation of the ABTS by potassium persulfate to form a radical cation 2,2'-azino-bis-3- ethylbenzothiazoline-6-sulphonic acid (ABTS+). The absorbance was taken at $734 \mathrm{~nm}$ and the activity was expressed as percentage inhibition of 2, 2'-azino-bis-3-ethylbenzothiazoline-6-sulphonic acid (ABTS) radicals.

\section{Hydrogen peroxide radical}

A solution of $40 \mathrm{mM} \mathrm{H}_{2} \mathrm{O}_{2}$ was prepared in phosphate buffer ( $\mathrm{pH}-7.4$ ). $1.4 \mathrm{ml}$ of different concentrations of the extracts was added to $0.6 \mathrm{ml}$ of the $\mathrm{H}_{2} \mathrm{O}_{2}$ solution. The assay mixture could stand for $10 \mathrm{~min}$ at $25^{\circ} \mathrm{C}$ and the absorbance was measured against a blank solution at $230 \mathrm{~nm} .{ }^{12}$

\section{Metal chelating activity}

The chelation of ferrous ions by terpenoids extract was estimated. The absorbance of the solution was measured at $562 \mathrm{~nm}$. The percentage inhibition of ferrozine-Fe2+ complex formation was calculated as [(A0- As)/ A0] X 100, where A0 was the absorbance of the control, and as was the absorbance of the extract/ standard..$^{13}$

\section{FRAP assay}

The FRAP (Ferric reducing antioxidant power assay) was assayed as per the protocol of Benzie and Strain. ${ }^{14}$ The absorbance of the reaction mixture was read at $593 \mathrm{~nm}$ spectrophotometrically after incubation at $37^{\circ} \mathrm{C}$ for $10 \mathrm{~min}$.

\section{FTIR spectroscopy}

FTIR spectrometer was used to collect spectra of different solvent extracts of the moss. ${ }^{15}$ The sample was mixed with KBr. The IR spectrum gives information about the functional groups. 4000 to $300 \mathrm{~cm}^{-1}$ is the range of measurements. The region above $1200 \mathrm{~cm}^{-1}$ shows spectral bands due to vibrations of individual functional groups whereas the region below $1200 \mathrm{~cm}^{-1}$ shows bands due to vibrations of whole molecule, and is known as the fingerprint region.

\section{RESULTS AND DISCUSSION}

Primary and secondary metabolite screening of T. tamariscellum revealed a tremendous range of biologically active compounds such as carbohydrates, lipid, protein, steroids, phenols, terpenoids, organic acids, sugar alcohols, fatty acids, aliphatic compounds, acetogenins, phenylquinones, and aromatic and phenolic substances which substantiates its significant bioactivities. The plant derived natural products occupy an important place in life style diseases such as cancer chemotherapy with minimal side effects.

\section{Total terpenoid content}

Subsequently, the total terpenoid content was analyzed. Significant level of terpenoid was noticed in the moss T. tamariscellum i.e., $25.95 \mathrm{mg} / \mathrm{g}$.

\section{DPPH scavenging effect}

This is one of the most common method used to analyze the free radical scavenging ability of the plant extracts. It is a stable free radical that accepts an electron in the presence of AOX, with a subsequent discolouration of the violet colour. The discoloration was stechiometrically related to the number of electrons accepted. A concentration dependent antioxidant activity was noticed with the terpenoid extract of the moss. The $\mathrm{IC}_{50}$ value of the extract was $16 \mu \mathrm{g} / \mathrm{ml}$. The following moss species such as Sphagnum cuspidatum subsp. subrecurvum, Sphagnum cuspidatulum, Sphagnum junghuhniannum, Pogonatum cirratum subsp. fuscatum and Pogonatum cirratum subsp. macrophyllum displyayed considerable DPPH scavenging property. ${ }^{8}$ The present data was at par with that of the moss species previously reported.

\section{Hydrogen peroxide scavenging}

The moss terpenoid extract showed a concentration dependent scavenging of the hydroxyl radical and the $\mathrm{IC}_{50}$ value was $34.5 \mu \mathrm{g} / \mathrm{ml}$. Hydrogen peroxide is basically a week oxidising agent, can cross cell membranes and react with ions like $\mathrm{Fe}^{2+}$ to form hydroxyl radical which is a strong oxidising agent and is toxic to the cell. This shows the moss extract can effectively scavenge hydroxyl radical. The values were statistically significant at $5 \%$ level.

\section{ABTS radical scavenging activity}

The terpenoid extract effectively scavenged the ABTS radicals in a dose dependent manner. At $30 \mu \mathrm{g} / \mathrm{ml}$ the inhibition was $65.45 \%$ and that of ascorbate was $79.5 \%$. The $\mathrm{IC}_{50}$ value of ascorbate was $10 \mu \mathrm{g} / \mathrm{ml}$ while that of moss terpenoid extract was $18.5 \mu \mathrm{g} / \mathrm{ml}$.

Fifilyana et al. ${ }^{8}$ reported that the aqueous, methanolic and ethanolic extract of the moss Pogonatum. cirratum subsp. fuscatum possess strong ABTS radical scavenging activity.

\section{Ferric reducing antioxidant power (FRAP) assay}

FRAP assay estimate the reducing potential of moss extract by reacting with a ferric tripyridyltriazine (Fe3+-TPTZ) complex to form a coloured ferrous tripyridyltriazine (Fe2+-TPTZ). Table 1 shows the ferric reducing power increased with an increase in concentration of the terpenoid 
Table 1: AOX potential of the terpenoid extract of the moss T. tamariscellum.

\begin{tabular}{|c|c|c|c|c|c|}
\hline \multicolumn{6}{|c|}{ Assays (\% of scavenging activity) } \\
\hline Concentration $(\mu \mathrm{g} / \mathrm{ml})$ & DPPH scavenging effect & $\begin{array}{l}\text { Hydrogen peroxide } \\
\text { scavenging }\end{array}$ & $\begin{array}{c}\text { ABTS radical } \\
\text { scavenging activity }\end{array}$ & FRAP assay & $\begin{array}{c}\text { Metal chelating } \\
\text { activity }\end{array}$ \\
\hline 10 & $37.7 \pm 4.2$ & $30.26 \pm 2.4$ & $45.17 \pm 0.89$ & $27.10 \pm 1.2$ & $32 \pm 1.46$ \\
\hline 20 & $56.4 \pm 3.9$ & $35.32 \pm 3.8$ & $52.07 \pm 1.6$ & $32.60 \pm 1.4$ & $34.65 \pm 2.8$ \\
\hline 30 & $72.94 \pm 6.2$ & $47.29 \pm 1.4$ & $65.45 \pm 3.4$ & $43.3 \pm 2.6$ & $44.12 \pm 4.2$ \\
\hline 40 & $86.16 \pm 5.8$ & $53.73 \pm 6.85$ & $74.24 \pm 1.4$ & $50.8 \pm 3.2$ & $55.28 \pm 3.5$ \\
\hline ASC (30) & $88.89 \pm 4.9$ & $70.15 \pm 6.4$ & $79.5 \pm 2.8$ & $58.32 \pm 5.2$ & $58.95 \pm 6.4$ \\
\hline
\end{tabular}

$(P<0.05)$

Table 2: FT-IR profile of functional groups $\left(\mathrm{cm}^{-1}\right)$ in Thuidium tamariscellum in various solvent extracts.

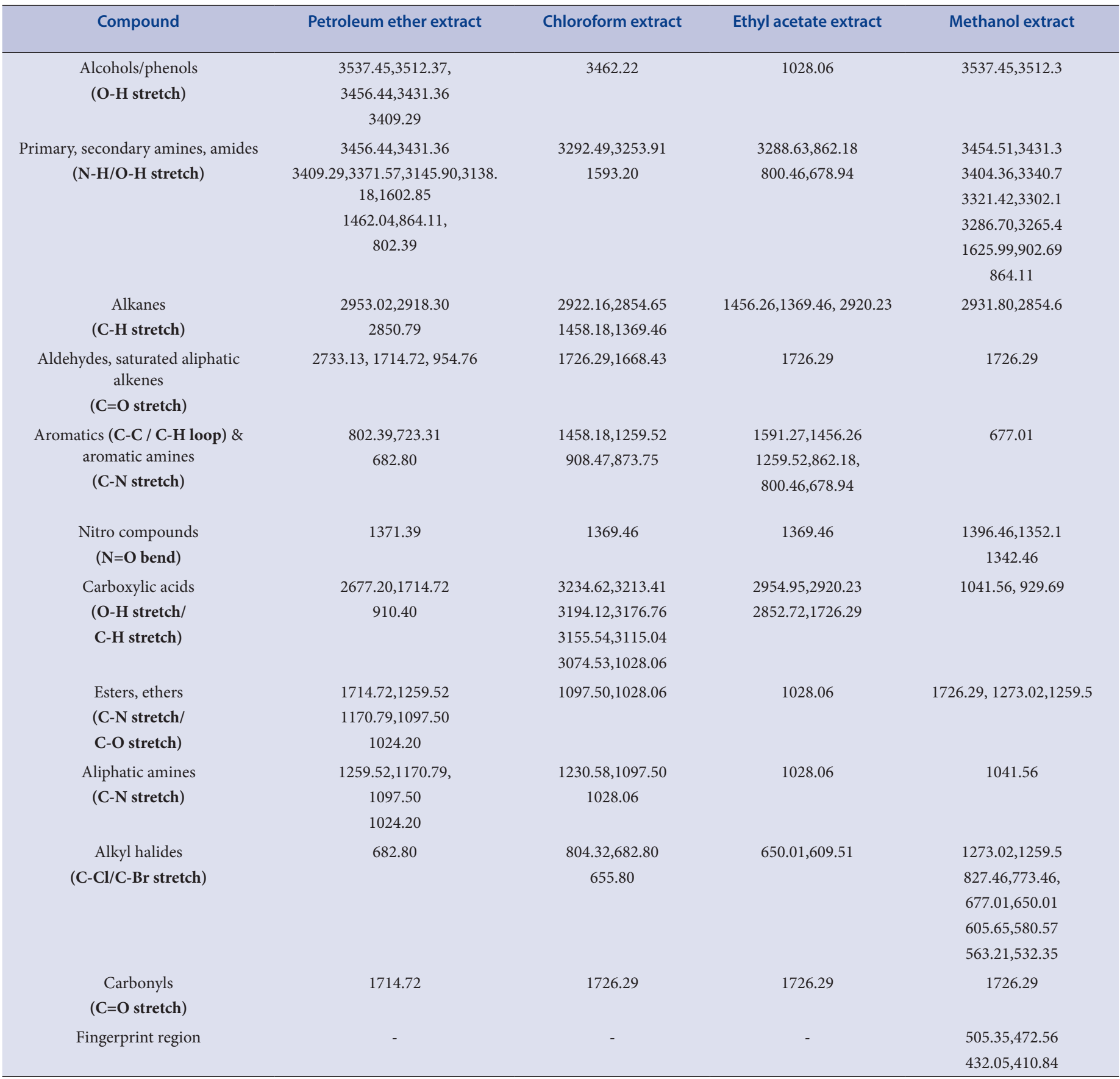




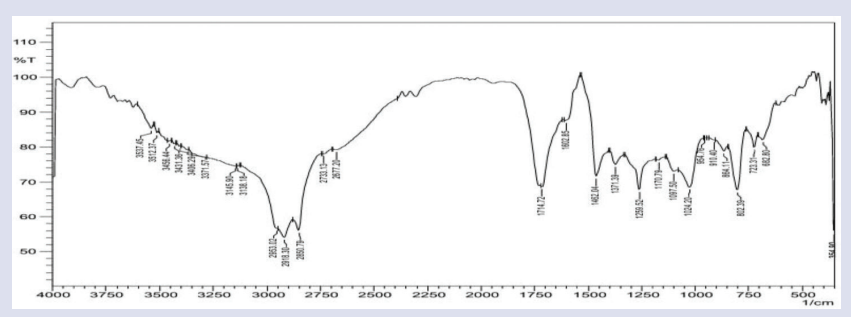

Figure 1a: FT-IR profile of functional groups $\left(\mathrm{cm}^{-1}\right)$ in Thuidium tamariscellum in petroleum ether extract.

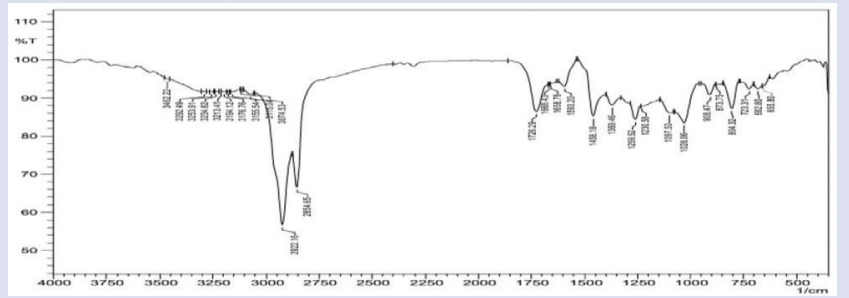

Figure b: FT-IR profile of functional groups $\left(\mathrm{cm}^{-1}\right)$ in Thuidium tamariscellum in chloroform extract.

extract. The $\mathrm{IC}_{50}$ of the terpenoid extract was $40 \mu \mathrm{g} / \mathrm{ml}$ while that of the synthetic antioxidant ascorbate was at $28 \mu \mathrm{g} / \mathrm{ml}$.

Homalothecium sericeum and Eurhynchium striatulum possess stronger ferric reducing power 36.91 and $33.59 \mu \mathrm{mol} / 100 \mathrm{~g}{ }^{16}$

\section{Metal chelating activity}

Table 1 shows a dose dependent increase in ferrous $\left(\mathrm{Fe}^{2+}\right)$ metal ion chelation. This property is mainly due to the presence of endogenous chelating agents like terpenoids in the plant extract. $40 \mu \mathrm{g} / \mathrm{ml}$ concentration of the extract showed $55.28 \%$ chelation of ferrous ions. The $\mathrm{IC}_{50}$ value of the moss terpenoid extract was at $35 \mu \mathrm{g} / \mathrm{ml}$ while that of ascorbate was at $22 \mu \mathrm{g} / \mathrm{ml}$.

Wojtunik et al. ${ }^{17}$ proposed a model on the antioxidant potential of terpenoids constituents in 2,2-diphenyl-1-picrylhydrazyl method. Thoppil et al. ${ }^{18}$ reviewed the role of terpenoids as chemopreventive and therapeutic against liver cancer. Zwenger and $\mathrm{Basu}^{19}$ evaluated the roles and future potentials of plant terpenoids. Partap and pandey ${ }^{20}$ compared herbal antioxidants of a medicinal species. Nagarajan and Brindha ${ }^{21}$ compared diterpenes therapeutic uses with special emphasis on antidiabetic activity. Topçu et al..$^{22}$ analyzed antioxidant potential of triterpenoids from Salvia macrochlamys. Kasote et al. ${ }^{23}$ proved remarkable nature of polyphenolics in terms of antioxidant potential to cure many life style diseases. Polyphenolic molecules contain one or many aromatic rings with hydroxyl groups. Generally, the antioxidant capacity of the phenolics is directly related with the number of free hydroxyls and conjugation of side chains with the aromatic rings. ${ }^{24}$ Flavonoids and phenolic acids of plant phenolics, are metabolically originated from the acetate via shikimate pathways, as well as the shikimate pathway from phenylalanine or tyrosine. ${ }^{25}$ Phytochemicals of this group are excellent antioxidants under in vitro and in vivo experimentals. In addition, they are proven to interplay with other natural antioxidants like ascorbate or tocopherol and to synergistically enhance their biological potentials. ${ }^{26}$ Flavonoids and phenylopropanoid derivatives are also oxidized by peroxidase, and act as $\mathrm{H}_{2} \mathrm{O}_{2}$ scavengers. ${ }^{27}$ In vitro experimental conditions showed that

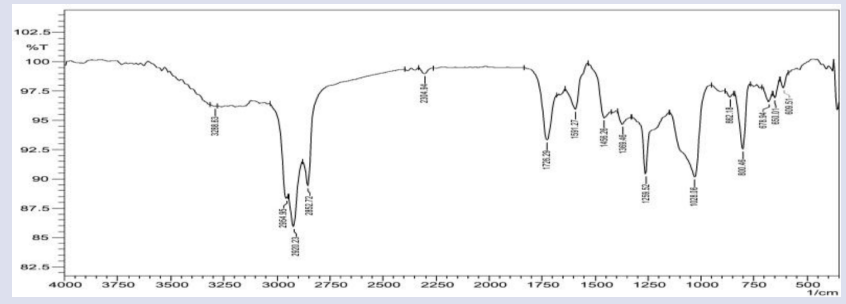

Figure c: FT-IR profile of functional groups $\left(\mathrm{cm}^{-1}\right)$ in Thuidium tamariscellum in ethyl acetate extract.

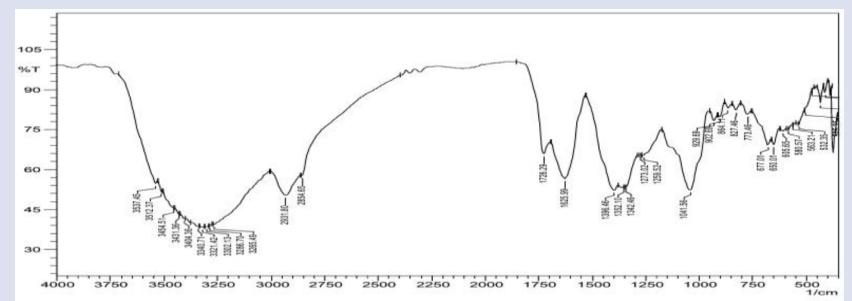

Figure d: FT-IR profile of functional groups $\left(\mathrm{cm}^{-1}\right)$ in Thuidium tamariscellum in methanol extract.

the antioxidant power of polyphenolics is always linked to their electron donation, reducing power and metal ion chelating ability. ${ }^{28}$ In this juncture, the present results were more significance in the sense that most of the proven works were from phenols or flavanoids. In the present study, the crude terpenoid content of the moss was high and displayed high antioxidant potentials.

\section{FTIR analysis}

The FTIR spectroscopic analysis of four different solvent extracts of T. tamariscellum showed the presence of various functional groups indicating the presence of bioactive compounds especially terpenes and terpenoids in the plant. Terpenoids were present with $\mathrm{C}=\mathrm{O}$ stretch in $1714.72 \mathrm{~cm}^{-1}$ in petroleum ether extract, $1726.29 \mathrm{~cm}^{-1}$ in ethyl acetate, chloroform and methanol extract and with $\mathrm{O}-\mathrm{H}$ stretch in $3409.29,3456.44$ and $3431.36 \mathrm{~cm}^{-1}$ in petroleum ether extract and $3404.36,3454.51,3431.3 \mathrm{~cm}^{-1}$ in methanol extract (Table 2). The presence of terpenes were also revealed due to $\mathrm{C}-\mathrm{H}$ stretch in 2953.02, 2918.30, 2850.79 in petroleum ether extract, 2920.23 in ethyl acetate extract, 2922.16, 2854.65 in chloroform extract and 2931.80, 2854.65 in methanolic extract (Figure 1a,b,c,d).

Hydroxyl group $\left(\sim 3400 \mathrm{~cm}^{-1}\right)$ or an oxo group (saturated 1750-1700 $\left.\mathrm{cm}^{-1}\right)$ indicates the presence of terpenoids. ${ }^{29}$ The peak at $2926.01 \mathrm{~cm}^{-1}$ in the ethanolic extract of Tylophora pauciflora indicating the C-H stretching of alkane compounds in the rare medicinal plant. ${ }^{30}$ In the methanolic extract of Rhapis excelsa C-H stretch at 2856.7- $2927.1 \mathrm{~cm}^{-1}$ also reveals terpenoids in terms of $\mathrm{C}=\mathrm{O}$ stretch at $1704.18,1708.04 \mathrm{~cm}^{-1} .^{31}$

\section{CONCLUSION}

The phytochemical study showed the presence of significant level of terpenoid in the moss which was validated by FTIR analysis showing peaks specific for terpenoids. Thus, the high antioxidant property shown by the plant is mainly due to the presence of considerable amount of terpenoids. Further studies are warranted to isolate the potential lead molecule and to evaluate its biological properties. 


\section{ACKNOWLEDGEMENT}

The authors are greatly thankful to the UGC-CSIR for providing the JRF fellowship

\section{ABBREVIATIONS}

FTIR: Fourier Transformer Infra-red; AOX: Antioxidant; ABTS: 2,2'-azino-bis-3-ethylbenzothiazoline-6-sulphonic acid assay; DPPH: 2,2-diphenyl-1-picryl-hydrazyl-hydrate.

\section{CONFLICT OF INTEREST}

The authors declare that there are no conflict of interest pertaining to this work.

\section{REFERENCES}

1. Manoj GS, Murugan K. Phenolic profiles, antimicrobial and antioxidant potentiality of methanolic extract of a liverwort Plagiochila beddomei steph. Ind J Nat Prod Res. 2012;3(2):173-83.

2. Saroya SA. Herbalism, Phytochemistry and Ethnopharmacology. Science Publishers. Enfield, New Hampshire. 2011;1-403.

3. Hu Y, Guo DH, Liu P, Rahman K, Wang XD, Wang B. Antioxidant effects of a Rhodobryum roseum extract and its active components in isoproterenolinduced myocardial injury in rats and cardiac myocytes against oxidative stresstriggered damage. Pharmazie. 2009;64(1):53-7.

4. Sharma C, Sharma A, Katoch M. Comparative evaluation of antimicrobial activity of methanolic extract and phenolic compounds of a liverwort, Reboulia hemispherica. Archive for bry. 2013;192.

5. Bhattarai $\mathrm{DH}$, Paudel $\mathrm{B}$, et al. Antioxidant activity of Sanionia uncinata, polar moss species from King George Island, Antartica. Phytother Res 2008;22(12):1635-9

6. Pejin B, Jelena BP, Pejin I, Sabovljevic M. Potential antioxidant activity of the moss Bryum moravicum. Nat Product Res. 2013;27(10):900-2.

7. Chobot V, Kubicova L, Nabbout S, Jahodar L, Hadacek F. Evaluation of Antioxidant Activity of Some Common Mosses. Z. Naturforsch. 2008;63(7-8):476-82.

8. Karim FA, Suleiman M, Rahmat A, Bakar MA. Phytochemicals, Antioxidant and Antiproliferative Properties of Five Moss Species from Sabah, Malaysia. Int J Pharm andPharma Sci. 2014;6(10):292-7.

9. Ferguson NM. A Text book of Pharmacognosy. MacMilan Company, New Delhi. 1956;191.

10. Blois M. Antioxidant determinations using a stable free radical. Nature 1958;181(4617):1199-200.

11. Herraiz T, Galisteo J. Endogenous and dietary indoles: a class of antioxidants and radical scavengers in the ABTS assay. Free Radical Res. 2004;38(3):323-31.

12. Delpour AA, Ebrahimzadeh MA, Nabawi SF, Nabavi SM. Antioxidant activity of the Methanol extract of Ferula asafetida and its essential oil composition. Grassy Aceites. 2009;60(4):405-12.
13. Dinis TCP, Madeira VMC, Almeida LM. Action of phenolic derivatives (acetaminophen, salicylate and 5-aminosalicylate) as inhibitors of membrane lipid peroxidation and as peroxyl radical scavengers. Arch Biochem Biophys. 1994;315(1):161-9.

14. Benzie IFF, Strain JJ. Ferric reducing/antioxidant power assay: direct measure of total antioxidant activity of biological fluids and modified version for simultaneous measurement of total antioxidant power and ascorbic acid concentration. Method Enzym. 1999;299:15-27.

15. Anilkumar VS, Dinesh-Babu KV, Sunukumar SS, Murugan K. Taxonomic discrimination of Solanum nigrum and S. giganteum by Fourier transform infrared spectroscopy Data. J Res Biol. 2012;2:482-8.

16. Ertürk O, Sahin H, Emine YE, Hilal EH, koz B, Ozlem özdemir. The antimicrobia and antioxidant activities of extracts obtained from some moss species in Turkey. Herba Polonica. 2015:61(4):52-65.

17. Wojtunik KA, Ciesla LM, Waksmundzka-Hajnos M. Model studies on the antioxidant activity of common terpenoid constituents of essential oils by means of the 2,2-diphenyl-1-picrylhydrazyl method J Agric Food Chem. 2014;62(37):9088-94

18. Thoppil R, Bishayee A. Terpenoids as potential chemopreventive and therapeutic agents in liver cancer. World J Hepatol. 2011;3(9):228-49.

19. Zwenger $\mathrm{S}$ and Basu HK. Plant terpenoids: applications and future potentials. Reviews. 2008:3(1):1-7.

20. Partap S, Pandey S. A Review on Herbal Antioxidants. J Pharma Phytochem. 2012;1(4):26-37.

21. Nagarajan A, Brindha P. Diterpenes-A Review on Therapeutic uses with special emphasis on Antidiabetic Activity. J Pharma Res. 2012:5(8):4530-40.

22. Topçu G, Ertas A, Kolak U, Öztürk M, Ulubelen A. Antioxidant activity tests on novel triterpenoids from Salvia macrochlamys. ARKIVOC. 2007;(7):195-208.

23. Kasote DM, Katyare SS, Hegde MV, Bae H. Significance of Antioxidan Potential of Plants and its Relevance to Therapeutic Applications. Int J Biol Sci. 2015:11(8):982-91.

24. Morgan JF, Klucas RV, Grayer RJ, Abian J, Becana M. Complexes of iron with phenolic compounds from soybean nodules and other legume tissues: prooxidan and antioxidant properties. Free Radic Biol Med. 1997;22(5):861-70.

25. Dewick PM. The Shikimate Pathway: Aromatic Amino Acids and Phenylpropanoids, in Medicinal Natural Products: A Biosynthetic Approach, $3^{\text {rd }}$ Edition. Chichester, UK: John Wiley and Sons, Ltd. 2009;137-86.

26. Croft KD. The chemistry and biological effects of flavonoids and phenolic acids Ann NY Acad Sci. 1998;854(1):435-42

27. Sakihama Y, Cohen MF, Grace SC, Yamasaki H. Plant phenolic antioxidant and prooxidant activities: phenolics-induced oxidative damage mediated by metals in plants. Toxicology. 2002;177(1):67-80.

28. Rice-Evans C, Miller N, Paganga G. Antioxidant properties of phenolic compounds. Trends Plant Sci. 1997;2(4):152-9.

29. Nita yadev, Rajesh yadev, Anju goyal. Chemistry of terpenoids. Int J Pharm Sci Rev Res. 2014;27(2):272-8.

30. Starlin T, Arul RC, Ragavendran P, Gopalakrishnan VK. Phytochemical screening functional groups and element analysis of Tylophora pauciflora wight and arn Int Res J Pharm. 2012;3(6):180-3.

31. Vanaja D, Kavitha S. A study on phytochemicals, antioxidant activity and ft-ir analysis of Rhapis excelsa (thunb.) A. Henry. Eur J Pharm Med Res. 2016:3(7):390-4
GRAPHICAL ABSTRACT

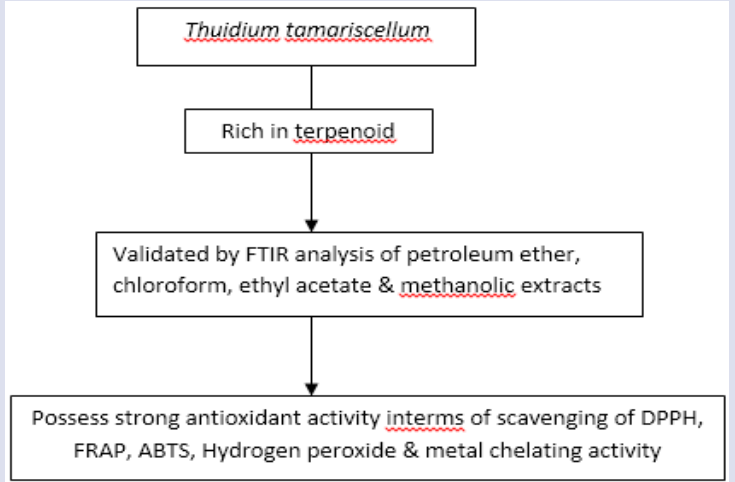

SUMMARY

- The moss Thuidium tamariscellum is rich in secondary metabolites especially terpenoids. This data was validated by FTIR analysis showing the presence of various functional groups indicating the presence of terpenes and terpenoids. Further, the effective scavenging of DPPH, ABTS, FRAP, Hydrogen peroxide and metal chelating activity by the terpenoid extract from the moss clearly establishes the antioxidant power of the bryophyte.

\section{ABOUT AUTHORS}

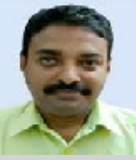

Dr. Murugan K: Was the Deputy Director of Collegiate Education (full additional charge), Govt. of Kerala, India. Currently, he is the Principal Govt. Arts College, Trivandrum. His research areas include the Biochemistry of natural dyes, Stress physiology and Molecular defence mechanisms.

Cite this article: Mohandas GG, Kumaraswamy M. Antioxidant Activities of Terpenoids from Thuidium tamariscellum (C. Muell.) Bosch. and Sande-Lac. a Moss. Pharmacog J. 2018;10(4):645-9. 